\title{
Bamboo particleboards: recent developments ${ }^{1}$
}

\author{
Christian Gauss², Victor De Araujo ${ }^{3}$, Maristela Gava ${ }^{4}$, \\ Juliana Cortez-Barbosa ${ }^{4}$, Holmer Savastano Junior ${ }^{2}$
}

\section{ABSTRACT}

Due to the high dimensional variation of bamboo, the manufacturing of materials such as plywood and laminated bamboo produces a high amount of residues. The production of particleboards could be used to overcome this problem and become a viable solution to reuse the generated waste as a raw material to high value-added products. This study aimed to present an overview of the bamboo particleboard production, as well as the mechanical and physical properties of this material, followed by a review of the advances in its research and development. In general, independently of the resin or bamboo species utilization, several bamboo particleboards meet the mechanical properties requirements of international standards for wood-based medium-density particleboards. The main focus of this study is to provide a review, in order to support research groups interested in using new bamboobased materials for the development of manufactured durable products.

KEYWORDS: Bamboo panels, bamboo-based materials, lignocellulosic materials.

\section{INTRODUCTION}

Bamboo is a fast growing plant of the Poaceae family, Bambusoideae subfamily, Bambuseae tribe (Sharma et al. 2015), that has attracted the curiosity of mankind since the early beginning of our civilization. Its use in Asia and in some countries of South America represents the people's lifestyle and is followed by mysticism and philosophy.

As a building material, bamboo has several advantages over other manmade materials, especially because it is a renewable resource. Its specific

\section{RESUMO}

\section{Painéis particulados de bambu: desenvolvimentos recentes}

Devido à grande variação dimensional do bambu, a produção de materiais como compensados e laminados produz grande quantidade de resíduos. A produção de painéis particulados poderia ser utilizada para superar este problema e tornar-se uma solução viável na reutilização dos resíduos gerados como matériaprima para produtos de alto valor agregado. Objetivou-se apresentar uma visão geral sobre a produção de painéis particulados de bambu, assim como suas propriedades mecânicas e físicas, acompanhada por uma revisão dos avanços em sua pesquisa e desenvolvimento. Em geral, independentemente da resina ou espécie de bamboo utilizadas, diversos painéis particulados de bambu atendem os requisitos de normas internacionais para painéis particulados de média densidade à base de madeira. $\mathrm{O}$ foco principal deste trabalho é fornecer uma revisão para apoiar grupos de pesquisa interessados em utilizar novos materiais à base de bambu para o desenvolvimento de produtos manufaturados duráveis.

PALAVRAS-CHAVE: Painéis de bambu, materiais à base de bambu, materiais lignocelulósicos.

mechanical properties are similar to timber, steel and concrete, and its use can be cost-effective (Ghavami 1992, Flander 2005). Additionally, bamboo forests accumulate up to four times the carbon density, in comparison with spruce forests, over a long term period (Yiping et al. 2010).

In the industry and as a commercial product, bamboo can be used for fiber and paper production, coal, laminates, beams, food and others (Pereira \& Beraldo 2007). Nowadays, the bamboo industry has developed into a multi-million dollar business internationally. The manufacturing of various

1. Received: Sep. 21, 2018. Accepted: May 21, 2019. Published: Jul. 04, 2019. DOI: 10.1590/1983-40632019v4955081.

2. Universidade de São Paulo, Departamento de Engenharia de Biossistemas, Pirassununga, SP, Brasil.

E-mail/ORCID: gausschr@usp.br/0000-0002-2046-7033, holmersj@usp.br/0000-0003-1827-1047.

3. Universidade de São Paulo, Departamento de Ciências Florestais, Piracicaba, SP, Brasil. E-mail/ORCID: victor@usp.br/0000-0002-2747-4738.

4. Universidade Estadual Paulista, Departamento de Engenharia Industrial Madeireira, Itapeva, SP, Brasil.

E-mail/ORCID: maristela.gava@unesp.br/0000-0003-0054-5927, juliana.cortez@unesp.br/0000-0003-0006-7945. 
products, however, produces a large amount of waste, especially in the processing phase (Kasim et al. 2001). More than $30 \%$ of the material is lost as shavings in the production of laminated bamboo, for example (Biswas et al. 2011, Sharma et al. 2014). As such, the bamboo industrialization must be accompanied by the use of this waste in the manufacturing of reconstituted products and for local energy generation, thus optimizing the material processing through its production chain.

The production of bamboo particleboards with environmentally friendly resins, combined with recent advances in processing technologies, can be economically feasible (Ganapathy et al. 1999). Indeed, countries like China, Malaysia, Costa Rica and Vietnam already have bamboo particleboards as a commercial product available in the market, although most of them using conventional synthetic resins.

The bamboo particleboard production processing steps are very similar to those of woodbased and other agricultural waste particleboards, and its production can be used as a complement of engineered bamboo products such as laminated bamboo, bamboo scrimber, bamboo lumber and others. In order to analyze the potentialities of this material, the present study describes briefly the recent researches in the production and characterization of bamboo particleboards and future developments that could be imagined with this review.

\section{THE BAMBOO PLANT}

There are over 1,200 bamboo species covering 70 genera around the world, found in cold, mild and tropical regions (Grosser \& Liese 1971, Gratani et al. 2008, Sharma et al. 2014). China has a high concentration of species (400 species from 50 genera) and a bamboo growing area of approximately 4.21 million ha (Qisheng \& Shenxue 2001). In Brazil, 232 species have been identified, corresponding to $89 \%$ of all the genera and $65 \%$ of all native bamboo species in South America (Pereira 2012). However, exotic species in Brazil, such as Dendrocalamus asper, Phyllostachys aurea, P. pubescens, Bambusa vulgaris and $B$. tuldoides, are widely well adapted and normally used for craftwork and civil construction.

Bamboo species are classified in different types of root system and growth behavior, i.e., monopodial (running), sympodial (clumping) and amphipodial (running or clumping). In clumping bamboos, culms grow close together, forming a stabilized clump, while running species have independent culms that spread like a normal grass.

The bamboo culm grows as a hollow cylindrical pole composed of regions with aligned and continuous fiber bundles, called internodes, separated by parts with solid transversal diaphragms and interwoven fiber bundles in the wall thickness, called nodes.

Bamboo is also known for its rapid growth, reaching up to $30 \mathrm{~m}$ within a year. After the complete growth, the culms gain strength continuously until optimum mechanical properties, at 3-5 years (mature culms), with enough structural resistance. In this aspect, there is no counterpart in the vegetal kingdom (Liese \& Weiner 1996, Pereira \& Beraldo 2007). It is well known that only mature culms should be used in civil construction (in natura or engineered), especially due to the higher mechanical resistance, dimensional stability and degradation resistance.

From an anatomical point of view, bamboo is composed of $40 \%$ of fiber bundles and $50 \%$ of parenchymal cells (phloem and parenchyma) and vessels (10\%) (Liese 1987, Li et al. 1994), as shown in Figure 1. Its fiber sheath is distributed in such a way that, along the thickness, a higher density of fibers is predominantly found in the external layer than in the internal layer. The culm diameter, thickness and internode length also change with the height position (Ghavami et al. 2003, Geroto 2014).

Due to its optimized fiber distribution and morphology, bamboo can be considered a functionally graded material, developed in order to resist wind forces and weather conditions (Nogata \& Takahashi 1995, Ghavami \& Marinho 2005).

\section{BAMBOO PARTICLEBOARDS}

The strong appeal of bamboo as a sustainable and abundant material, plus its unique intrinsic properties, has received the attention of several universities and institutions worldwide. It is possible to notice an increased trend in the number of publications related to the bamboo scientific research. According to the Scopus database, until September 2016, a total of 10,094 publications related to bamboo had been published, concentrated in recent years. All these studies were developed in the areas of agricultural and biological sciences, engineering, materials science, environmental science, chemistry 

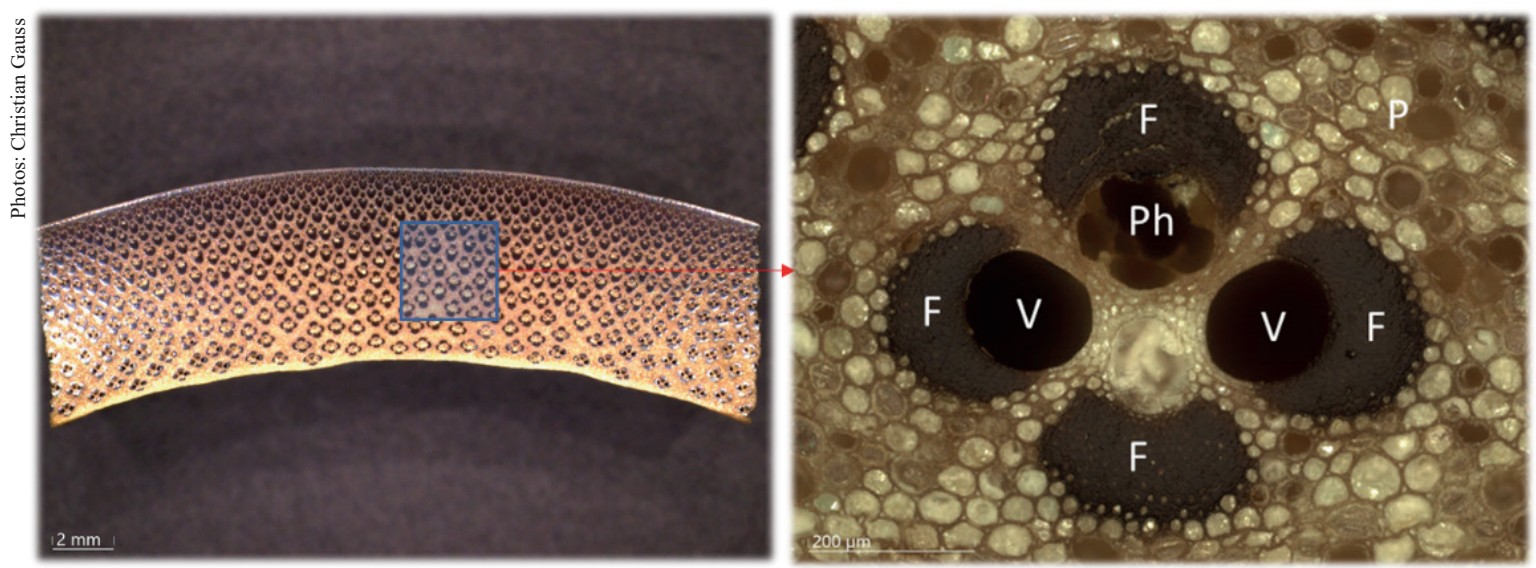

Figure 1. Anatomical overview of a bamboo culm. V: vessels; F: fiber bundles; Ph: phloem; P: parenchyma.

and energy. It is worth mentioning that, among these publications, only 53 are related to bamboo particleboards, and only a few of them approach the production of particleboards using organic resins.

Bamboo particleboards have been developed in Canada (in collaboration with Costa Rica), China, India and Vietnam (Ganapathy et al. 1999). Although there are no competitive engineered bamboo industries in Brazil, a high local potential, regarding the bamboo plantation and commercialization, makes reasonable to perform scientific research related to the development of high value-added products using bamboo. In fact, several studies have been made in Brazil using agricultural waste for the particleboard production (Calegari et al. 2007, Fiorelli et al. 2012a, Fiorelli et al. 2012b, Fiorelli et al. 2014, Belini et al. 2014, Valarelli et al. 2014, Zaia et al. 2015).

Qisheng et al. (2001) classified bamboo panels according to their material composition and product structure: bamboo-plywood products, laminated products (laminated bamboo from strips), chipboard products (bamboo chip/particleboard) and composite board products. Since bamboo particleboards are normally produced using culm tops and bamboo processing residues, the supply of raw material is abundant and economically affordable. Its raw material utilization ratio is very high, and the technologies required for the bamboo particleboard production are similar to those of wood particleboards.

Bamboo particleboards are normally produced by a mixture of bamboo particles (of a determined size) with resin. The resin normally consists of an organic adhesive: urea formaldehyde, phenol formaldehyde, castor oil-based polyurethane resin, polyvinyl acetate (PVA) and others. The following processes are normally performed for the production of bamboo particleboards: the obtained bamboo chips/particles are dried, mixed with resin, pre-formed and hot-pressed in the form of panels (Valarelli et al. 2014).

\section{MECHANICAL AND PHYSICAL PROPERTIES}

Commercial or laboratory-made particleboards are commonly produced, characterized and evaluated according to national and international standards, such as the British BS 5669 (BSI 1989), American ANSI A208.1 (ANSI 2016), Brazilian NBR 14810/2 (ABNT 2013), German DIN 68761 (DIN 1986), Indian IS 3087 (BIS 2005) and Japanese JIS A5908 (JSA 2015) wood particleboard standards. Density, thickness swelling, water absorption, modulus of elasticity (MOE), modulus of rupture (MOR) and internal bond strength are normally investigated during the particleboard development.

Ganapathy et al. (1999) described the commercial bamboo particleboard manufacturing processes employed in several countries. The physical and mechanical properties of these panels can be seen in Table 1. Similar densities can be observed with MOR and MOE ranging from 16.5 MPa to $27.4 \mathrm{MPa}$ and $2.48 \mathrm{GPa}$ to $4.15 \mathrm{GPa}$, respectively. These results show that bamboo particleboards may have a strength equivalent to conventional wood particleboards of similar density $(\mathrm{MOE}=2.76-4.14 \mathrm{GPa}$; MOR $=15.17-24.13 \mathrm{MPa})($ Robert 2010). 
Several studies have been developed using bamboo particles as material for the particleboard production. An overview of the obtained properties of several authors is presented in Tables 2 and 3. In Table 2, the processing conditions are shown, including the normative document used as a reference for the performance evaluation.

In general, all published studies follow the same production routine. First, the bamboo particles are obtained through conventional milling, followed by screening to eliminate fine and large particles, drying, resin impregnation, molding and hot pressing (in some cases, pre-pressing is performed).
Pressing conditions and resin formulations are also in Table 2.

Table 3 presents the mechanical and physical properties of investigated panels. Since there is no international standard for bamboo particleboards, the standard documents used for the comparison were those for wood-based boards.

Most of the investigated bamboo particleboards meet the normative requirements for medium density solutions and, in some cases, exceed the requirements, especially in Zaia et al. (2015), where a MOR of $38.0 \mathrm{MPa}$ and MOE of $5.9 \mathrm{GPa}$ were found. These results are related to the higher density

Table 1. Mechanical properties of commercial bamboo particleboards.

\begin{tabular}{lcccc}
\hline \multirow{2}{*}{ Properties } & \multicolumn{4}{c}{ Country } \\
\cline { 2 - 5 } \multicolumn{1}{c}{ China } & Costa Rica & Malaysia & Vietnam \\
\hline Resin & $\mathrm{SR} 8-12 \mathrm{wt} \%$ & $\mathrm{PF} 4 \mathrm{wt} \%$ & UF $10 \mathrm{wt} \%$ & UF $9-11 \mathrm{wt} \%$ \\
Pressing aspects & $0.4 \mathrm{~min} \mathrm{~mm}^{-1} ; 150-160{ }^{\circ} \mathrm{C} ; 1.14-1.18 \mathrm{MPa}$ & $3 \mathrm{~min} ; 215^{\circ} \mathrm{C}$ & $6 \mathrm{~min} ; 160^{\circ} \mathrm{C}$ & $12 \mathrm{~min} ; 120-140{ }^{\circ} \mathrm{C} ; 2.2-2.4 \mathrm{MPa}$ \\
Density & $730-800 \mathrm{~kg} \mathrm{~m}^{-3}$ & $750 \mathrm{~kg} \mathrm{~m}^{-3}$ & $720 \mathrm{~kg} \mathrm{~m}^{-3}$ & $650-720 \mathrm{~kg} \mathrm{~m}^{-3}$ \\
Moisture content & $6.9 \%$ & - & - & - \\
Water absorption $(24 \mathrm{~h})$ & - & $57 \%$ & - & $40.9 \%$ \\
Thickness swelling & $1.6 \%$ & $14 \%$ & $7.6 \%$ & $3.5 \%$ \\
Internal bond strength & $0.64 \mathrm{MPa}$ & $0.34 \mathrm{MPa}$ & $0.85 \mathrm{MPa}$ & $1.05-1.50 \mathrm{MPa}$ \\
Modulus of rupture & $24.24 \mathrm{MPa}$ & $17.2 \mathrm{MPa}$ & $27.4 \mathrm{MPa}$ & $16.5-17.5 \mathrm{MPa}$ \\
Modulus of elasticity & $2,480 \mathrm{MPa}$ & $3,100 \mathrm{MPa}$ & - & $4,150 \mathrm{MPa}$ \\
\hline
\end{tabular}

SR: synthetic resin; PF: phenol formaldehyde; UF: urea formaldehyde. Source: adapted from Ganapathy et al. (1999)

Table 2. Summary of bamboo particleboards processing conditions by several authors.

\begin{tabular}{|c|c|c|c|c|c|}
\hline \multicolumn{5}{|c|}{ Particleboards } & \multirow[b]{2}{*}{ Reference } \\
\hline $\begin{array}{l}\text { Bamboo species } \\
\text { (particle size) }\end{array}$ & $\begin{array}{l}\text { Bamboo age/ } \\
\text { origin }\end{array}$ & $\begin{array}{c}\text { Used } \\
\text { standards }\end{array}$ & $\begin{array}{c}\operatorname{Resin}^{1} \\
\text { (content wt\%) }\end{array}$ & $\begin{array}{l}\text { Pressing } \\
\text { aspects }\end{array}$ & \\
\hline $\begin{array}{l}\text { Gigantochloa scortechinii } \\
(0.5-2.0 \mathrm{~mm})\end{array}$ & $\begin{array}{l}1-3 \text { years } \\
\text { Malaysia }\end{array}$ & BS 5669 & UF (8-12\%) & $\begin{array}{l}160^{\circ} \mathrm{C} ; 6 \mathrm{~min} \\
11.8 \mathrm{MPa}\end{array}$ & Kasim et al. (2001) \\
\hline $\begin{array}{l}\text { Bambusa vulgaris } \\
(1.0-3.0 \mathrm{~mm})\end{array}$ & $\begin{array}{l}3 \text { years } \\
\text { Greece }\end{array}$ & $\begin{array}{l}\text { ANSI A208.1, } \\
\text { EN 310/317/319 }\end{array}$ & UF (10-14\%) & $\begin{array}{l}200^{\circ} \mathrm{C} ; 6 \mathrm{~min} \\
3.4 \mathrm{MPa}\end{array}$ & $\begin{array}{l}\text { Papadopoulos et al. } \\
\text { (2004) }\end{array}$ \\
\hline $\begin{array}{l}\text { B. vulgaris } \\
(1.0-4.0 \mathrm{~mm})\end{array}$ & Brazil & $\begin{array}{l}\text { ANSI A208.1, } \\
\text { DIN 68761-1/3 }\end{array}$ & UF (10\%) & $\begin{array}{l}120^{\circ} \mathrm{C} ; 8 \mathrm{~min} \\
4.4 \mathrm{MPa}\end{array}$ & Calegari et al. (2007) \\
\hline $\begin{array}{l}\text { B. vulgaris, } B . \text { balcão } \\
\text { (greater sizes }<38 \mathrm{~mm} \text { ) }\end{array}$ & $\begin{array}{c}- \\
\text { Bangladesh }\end{array}$ & $\begin{array}{l}\text { IS } 3087, \text { BS } 5669, \\
\text { DIN } 68761\end{array}$ & UF (10\%) & $\begin{array}{l}140^{\circ} \mathrm{C} ; 6 \mathrm{~min} \\
3.5 \mathrm{MPa}\end{array}$ & Biswas et al. (2011) \\
\hline $\begin{array}{l}\text { Guadua magna } \\
(1.0-3.0 \mathrm{~mm})\end{array}$ & $\begin{array}{c}- \\
\text { Brazil }\end{array}$ & ANSI A208.1 & $\begin{array}{l}\text { UF }(8 \%) \\
\text { PF }(8 \%)\end{array}$ & $\begin{array}{l}170^{\circ} \mathrm{C} ; 10 \mathrm{~min} \\
4.0 \mathrm{MPa}\end{array}$ & Arruda et al. (2011) \\
\hline $\begin{array}{l}\text { Dendrocalamus giganteus } \\
(1.2-4.0 \mathrm{~mm})\end{array}$ & $\begin{array}{l}4.5 \text { years } \\
\text { Brazil }\end{array}$ & NBR 14810/2 & $\begin{array}{l}\text { CP }(6-12 \%), \\
\text { UF }(6-12 \%)\end{array}$ & $\begin{array}{l}70-130{ }^{\circ} \mathrm{C} ; 10 \mathrm{~min} \\
4.0 \mathrm{MPa}\end{array}$ & Valarelli et al. (2014) \\
\hline $\begin{array}{l}\text { D. giganteus } \\
(3.0-7.0 \mathrm{~mm})\end{array}$ & $\begin{array}{l}5 \text { years } \\
\text { Brazil }\end{array}$ & NBR 14810/2 & $\mathrm{CP}(15 \%)$ & $\begin{array}{l}100^{\circ} \mathrm{C} ; 10 \mathrm{~min} ; \\
3.5 \mathrm{MPa}\end{array}$ & Zaia et al. (2015) \\
\hline $\begin{array}{l}\text { D. asper, G. apus, G. atroviolacea } \\
(2.0-4.8 \mathrm{~mm})\end{array}$ & $\begin{array}{c}- \\
\text { Indonesia }\end{array}$ & JIS A5908 & CA $(15-30 \%)$ & $\begin{array}{l}180^{\circ} \mathrm{C} ; 10 \mathrm{~min} \\
3.0 \mathrm{MPa}\end{array}$ & $\begin{array}{l}\text { Widyorini et al. } \\
(2016)\end{array}$ \\
\hline $\begin{array}{l}\text { D. asper } \\
(0.2-0.5 \mathrm{~mm})\end{array}$ & $\begin{array}{c}\text { 3-4 years } \\
\text { Brazil }\end{array}$ & NBR 14810/2 & UF (10\%) & $\begin{array}{l}180^{\circ} \mathrm{C} ; 10 \mathrm{~min} \\
3.4 \mathrm{MPa}\end{array}$ & Bazzetto et al. (2019) \\
\hline
\end{tabular}

UF: urea formaldehyde; PF: phenol formaldehyde; CP: castor oil polyurethane; CA: citric acid. BS 5669 (BSI 1989); ANSI A208.1 (ANSI 2016); EN 310 (BSI 1993); EN 317 (BSI 1993); EN 319 (BSI 1993); DIN 68761 (DIN 1986); IS 3087 (BIS 2005); NBR 14810/2 (ABNT 2013); JIS A5908 (JSA 2015). 
Table 3. Physical and mechanical properties of bamboo particleboards, according to the processing conditions of Table 2.

\begin{tabular}{|c|c|c|c|c|c|c|}
\hline \multicolumn{6}{|c|}{ Physical and mechanical properties ${ }^{1}$} & \multirow{2}{*}{ Reference } \\
\hline $\mathrm{D}\left(\mathrm{kg} \mathrm{m}^{-3}\right)$ & WA $(\%)$ & TS $(\%)$ & IB $(\mathrm{MPa})$ & MOR (MPa) & MOE (MPa) & \\
\hline $561-721$ & $34.0-57.7$ & $9.2-20.9$ & $0.48-1.04$ & $11.6-24.2$ & $1,985-3,544$ & Kasim et al. (2001) \\
\hline $739-755$ & - & $6.8-23.1$ & $0.65-0.95$ & $13.9-19.0$ & - & Papadopoulos et al. (2004) \\
\hline 590 & 65.6 & 17.9 & 0.18 & 12.0 & 2,629 & Calegari et al. (2007) \\
\hline 820 & 45.3 & 14.0 & - & 19.2 & 2,345 & \multirow{2}{*}{ Biswas et al. (2011) } \\
\hline 800 & 46.7 & 14.6 & - & 18.0 & 2,637 & \\
\hline 640 & 77.19 & 21.86 & 0.32 & 13.44 & 1,819 & \multirow{2}{*}{ Arruda et al. (2011) } \\
\hline 650 & 81.77 & 18.20 & 0.26 & 13.60 & 1,723 & \\
\hline $641-679$ & $74.1-63.7$ & $22.7-8.2$ & - & $3.73-5.64$ & $351-757$ & \multirow{2}{*}{ Valarelli et al. (2014) } \\
\hline $611-667$ & $74.4-43.7$ & $17.2-7.8$ & - & $2.43-9.86$ & $678-1,750$ & \\
\hline 910 & - & - & 3.01 & 38.0 & 5,855 & Zaia et al. (2015) \\
\hline \multirow{3}{*}{$840-950$} & $35.0-15.0$ & $9.0-4.0$ & $0.34-0.57$ & $11.0-14.0$ & $3,300-4,800$ & \multirow{3}{*}{ Widyorini et al. (2016) } \\
\hline & $17.0-13.0$ & $7.0-3.0$ & 0.37 & 13.0 & $3,900-4,000$ & \\
\hline & $26.0-12.0$ & $5.0-2.0$ & $0.40-0.42$ & $13.5-15.0$ & $3,700-4,000$ & \\
\hline \multirow{2}{*}{$580-590$} & $34.4-42.1$ & $6.7-8.0$ & \multirow{2}{*}{$0.25-0.28$} & \multirow{2}{*}{$5.2-7.6$} & 6 & \multirow{2}{*}{ Bazzetto et al. (2019) } \\
\hline & $42.2-45.4$ & $8.9-9.4$ & & & 1 & \\
\hline
\end{tabular}

D: density; WA: water absorption (24 h); TS: thickness swelling; IB: internal bond; MOR: modulus of rupture; MOE: modulus of elasticity.

of the developed board. However, no information about water absorption or thickness swelling was provided. In addition, the removal of starch before the particleboard production did not result in differences in the mechanical properties. No starch influence was found in the curing behavior of the castor oil-based polyurethane resin. No durability testing was performed to certify this structural panel under weather exposition.

Kasim et al. (2001) studied the effect of the bamboo culm age, urea formaldehyde content and nominal density on the mechanical and physical properties of particleboards of Gigantochloa scortechinii bamboo. It was found that the particleboards produced from all age groups (1-3 years) met the strength requirements specified in the BS 5669 (BSI 198) standard at densities over $641 \mathrm{~kg} \mathrm{~m}^{-3}$ and at all resin contents (8-12\%). In the case of single-layer particleboards (particles with $0.5-2.0 \mathrm{~mm}$ ), the different bamboo ages had a slight influence on water absorption, MOR, MOE, internal bond strength and thickness swelling. There was a decrease of MOR and water absorption and an increase of MOE, internal bond and thickness swelling with age. The resin content and nominal density were the main issues that influenced the mechanical and physical properties. The authors also observed that the three-layer particleboard of core with 1-mm particle size showed a higher water absorption and thickness swelling than a 2-mm particle size-core one. However, fine particles increased the internal bond strength, produced a smoother surface and the highest MOR (28.88 MPa). In general, the strength values were similar to those conditions for single-layer panels.

During the particleboard production, the different bamboo particle size and morphology may influence in the mechanical behavior of the material, surface roughness and dimensional stability. Biswas et al. (2011) showed that particleboards made of bamboo planer waste of Bambusa balcooa had a MOE $27 \%$ lower than particleboards produced from chips. The authors did not officially declare the particle dimensions, although larger ones (chips) had thickness lower than $38 \mathrm{~mm}$ - according to the smaller strip sizes refined in the hammer mill. Thus, planer waste was still lower than such size. In addition, particleboard dimensions were $500 \mathrm{~mm} \mathrm{x}$ $500 \mathrm{~mm} \times 12 \mathrm{~mm}$. The same behavior was observed with the $B$. vulgaris species, what may be explained by the fact that bamboo chips, due to their long and thin morphology, are more elastic than planer waste.

Bazzetto et al. (2019) verified the effects of different particle sizes on the particleboard properties based on Dendrocalamus asper bamboo chips glued with urea-formaldehyde. In this study, four size classes were selected, from $0.2 \mathrm{~mm}$ to $0.5 \mathrm{~mm}$, whose results revealed that the sizes used in those panels had no significant effect on water absorption, density, thickness swelling ( $24 \mathrm{~h}$ ), internal bonding and screw withdraw resistance (face/side). However, the same authors also evinced that a significant effect 
was verified for water absorption ( $2 \mathrm{~h}$ and $24 \mathrm{~h}$ ), thickness swelling (2 h), MOE and MOR.

Since the majority of the analyzed papers used different processing conditions, comparisons among the different authors may be difficult. On the other hand, there are some important considerations that can be made according to the summaries shown in Tables 2 and 3. Considering the same bamboo species (B. vulgaris), according to Papadopoulos et al. (2004), Calegari et al. (2007) and Biswas et al. (2011), it is possible to infer that the processing parameters do not have a strong effect on the final mechanical properties of particleboards with the same resin content (urea formaldehyde). They obtained MOR values of 12-19.2 MPa and MOE of 2,344.72,626.0 $\mathrm{MPa}$, even using different pressing times (6-8 $\mathrm{min})$ and temperatures $\left(120-200{ }^{\circ} \mathrm{C}\right)$, but with the same resin and resin content $(10 \mathrm{wt} \%)$.

\section{EFFECT OF RESINS}

Through the analysis of the mechanical and physical properties shown in Table 3, it is possible to analyze the effect of the resin on the performance of panels.

In general, urea formaldehyde resins show a good balance among the studied properties. However, during the manufacturing and drying processes, urea-formaldehyde and phenol formaldehyde release gases toxic to the human health and the environment. This may counteract the beneficial environmental effect of using bamboo as a raw material. Therefore, the use of castor oil-based polyurethane and citric acid becomes an interesting option, considering their low toxicity and for being a renewable resource (Valarelli et al. 2014, Widyorini et al. 2016).

The castor oil-based resin has been used in several researches on agricultural waste, bamboo and wood particleboards, showing good mechanical and physical properties and meeting the normative requirements (Fiorelli et al. 2012a and 2012b). Although very good results were also obtained in bamboo particleboards produced using castor oil-based resin in the study by Zaia et al. (2015), Valarelli et al. (2014) found better overall results using urea formaldehyde resin in bamboo particleboards with Dendrocalamus asper waste (branches and stem apical part).

Kasim et al. (2001) and Papadopoulos et al. (2004) studied the effect of wax addition (1\%) to the particleboards with urea formaldehyde resin and noticed a considerable decrease in the thickness swelling in all cases, meaning a lower water absorption and higher dimensional stability. Kasim et al. (2001) observed a reduction of $42 \%$ and $49 \%$ for thickness swelling and water absorption, respectively. For Papadopoulos et al. (2004), only particleboards bonded with $14 \%$ and $1 \%$ of wax were able to meet to the ANSI A208.1 (ANSI 2016) and EN 312 (BSI 2010) thickness swelling requirements.

Widyorini et al. (2016) used citric acid as an alternative bamboo particleboard binder ( $60 \mathrm{wt} \%$ of citric acid solution sprayed onto bamboo particles at $15 \mathrm{wt} \%$ and $30 \mathrm{wt} \%$ resin content). Improved dimensional stability and mechanical properties were found (Table 3), meeting the requirements of the JIS A5908 (JSA 2015) standard. Infrared analysis revealed that carboxyl groups from citric acid were ester linked with hydroxyl groups of bamboo, enhancing the dimensional stability.

\section{EFFECT OF SPECIES}

Widyorini et al. (2016) investigated the effect of species on the mechanical and physical properties of particleboards produced with citric acid. Since most bamboo species have a similar chemical composition, considerable differences were not observed among the analyzed species. The constituents alpha cellulose (AC), hemicellulose (He) and lignin (L) are quite similar among the bamboo species Dendrocalamus asper $(\mathrm{AC}=43.41 \% ; \mathrm{He}=$ $29.58 \% ; \mathrm{L}=24.00 \%$ ), Gigantochloa atroviolacea $(\mathrm{AC}=42.38 \% ; \mathrm{He}=30.27 \% ; \mathrm{L}=22.71 \%)$ and Gigantochloa apus $(\mathrm{AC}=69.27 \% ; \mathrm{He}=24.08 \%$; $\mathrm{L}=24.16 \%$ ).

The same was observed in the study by Biswas et al. (2011), where similar properties of particleboards produced with Bambusa vulgaris and $B$. balcooa were found. It is worth mentioning that, although both species meet the international standard requirements, $B$. vulgaris produced a higher glueability than $B$. balcooa.

Papadopoulos et al. (2004), Kasim et al. (2001) and Valarelli et al. (2014) investigated the production and characterization of bamboo particleboards using Gigantochloa scortechinii, Bambusa vulgaris and Dendrocalamus giganteus, respectively. Although different species and pressing conditions were used, there are samples with similar resin content 
(urea formaldehyde), density and particle size in the three studies. The particleboard with $10 \mathrm{wt} \%$ of resin content and density of $721 \mathrm{kgm}^{-3}$ in the study by Kasim et al. (2001) presented MOR of 20.21-24.40 MPa, MOE of 3,330-2,934 MPa, internal bond of $0.68-0.88 \mathrm{MPa}$, water absorption of $37.16-42.91 \%$ and thickness swelling of 12.69 $15.08 \%$, depending on the bamboo age (1-3 years old). Papadopoulos et al. (2004), using a different species, obtained MOR of $13.85 \mathrm{MPa}$, internal bond of $0.62 \mathrm{MPa}$ and thickness swelling of $23.1 \%$ for particleboards with $10 \%$ of resin content and density of $754 \mathrm{kgm}^{-3}$. Using D. giganteus, Valarelli et al. (2014) obtained a lower MOR (7.48 MPa) and MOE $(1,515.55 \mathrm{MPa})$ and thickness swelling $(8.58 \%)$ values, if compared to the other two studies, in particleboards with $10 \%$ of resin content. Although different bamboo species were used in the three studies, it was not clear if the observed differences are related to the species, characterization methods or manufacturing process.

\section{FINAL CONSIDERATIONS}

Through this review article, an overview of the available research on bamboo particleboards was performed. After the analysis of the gathered information, the following aspects are advised to be investigated in future studies related to bamboo particleboards, especially for the use in civil construction: heat absorption, fire resistance and treatment, acoustic isolation, water resistance improvement and development of new bio-based resins.

These items are very important for a further development of bamboo particleboards, especially to improve its competitiveness in relation to other commercially available materials.

\section{CONCLUSIONS}

The manufacturing of bamboo particleboards may be considered a quite interesting option to complement the engineered bamboo production chain. Most of the produced particleboards shown in this review met international standards for wood particleboards, mainly the mechanical properties. The water absorption and thickness swelling, however, still need to be improved. Nevertheless, the development of formaldehyde-free particleboards using castor oil-based resin or citric acid has shown a high potential as a commercial product.

The most important parameters that directly influence the particleboards performance are the resin content, density and particle size/morphology. In general, the modulus of rupture, modulus of elasticity, internal bond, thickness swelling and water absorption of the evaluated particleboards are found in the range of 6-38 MPa, 0.7-5.8 GPa, 0.2-3.0 MPa, $2-23 \%$ and $12-82 \%$, respectively.

Further investigations should be conducted in order to improve the bamboo particleboards properties, providing enough scientific background for future entrepreneurs. In addition, the simpler production process and the fact that different species of bamboo could indicate low costs and abundant resource for the manufacturing of particleboards make this raw material a suitable alternative for housing and furniture application.

\section{REFERENCES}

AMERICAN NATIONAL STANDARDS INSTITUTE (ANSI). ANSI A208.1-2016: particleboard. Gaithersburg: ANSI, 2016.

ARRUDA, L. M. et al. Lignocellulosic composites from Brazilian giant bamboo (Guadua magna): part 1: properties of resin bonded particleboards. Maderas: Ciencia y Tecnología, v. 13, n. 1, p. 49-58, 2011.

ASSOCIAÇÃO BRASILEIRADE NORMAS TÉCNICAS (ABNT). NBR 14810/2: painéis de partículas de média densidade: parte 2: requisitos e métodos de ensaio. Rio de Janeiro: ABNT, 2013.

BAZZETTO, J. T. L.; BORTOLETTO JUNIOR, G.; BRITO, F. M. S. Effect of particle size on bamboo particle board properties. Floresta e Ambiente, v. 26, n. 2, p. 1-8, 2019.

BELINI, U. L. et al. Painel multicamada com reforço de partículas de bambu. Scientia Forestalis, v. 42, n. 103, p. 421-427, 2014.

BISWAS, D.; BOSE, S. K.; HOSSAIN, M. M. Physical and mechanical properties of urea formaldehyde-bonded particleboard made from bamboo waste. International Journal of Adhesion and Adhesives, v. 31, n. 2, p. 84-87, 2011.

BRITISH STANDARD INSTITUTION (BSI). BS 5669: particleboard: methods of sampling, conditioning and test. London: BSI, 1989.

BRITISH STANDARD INSTITUTION (BSI). EN 310: wood-based panels: determination of modulus of 
elasticity in bending and of bending strength. London: BSI, 1993.

BRITISH STANDARD INSTITUTION (BSI). EN 312: particleboards: specifications. London: BSI, 2010.

BRITISH STANDARD INSTITUTION (BSI). EN 317: particleboards and fibreboards: determination of swelling in thickness after immersion in water. London: BSI, 1993.

BRITISH STANDARD INSTITUTION (BSI). EN 319: particleboards and fibreboards: determination of tensile strength perpendicular to the plane of the board. London: BSI, 1993.

BUREAU OF INDIAN STANDARDS (BIS). IS 3087: practice boards of wood and other lignocellulosic materials (medium density) for general purposes: specification. New Delhi: BIS, 2005.

CALEGARI, L. et al. Desempenho físico-mecânico de painéis fabricados com bambu (Bambusa vulgaris Schr.) em combinação com madeira. Cerne, v. 13, n. 1, p. 5763, 2007.

DEUTSCHES INSTITUT FÜR NORMUNG (DIN). DIN 68761: particle boards, flat pressed boards for general purposes, FPY-board. Berlin: DIN, 1986.

FIORELLI, J. et al. Particleboard with waste wood from reforestation. Acta Scientiarum: Technology, v. 36, n. 2, p. 251-256, 2014.

FIORELLI, J. et al. Particulate composite based on coconut fiber and castor oil polyurethane adhesive: an eco-efficient product. Industrial Crops and Products, v. 40, n. 1, p. 69$75,2012 \mathrm{a}$.

FIORELLI, J. et al. Sugarcane bagasse and castor oil polyurethane adhesive-based particulate composite. Materials Research, v. 16, n. 2, p. 439-446, 2012 b.

FLANDER, K. de. The role of bamboo in global modernity: from traditional to innovative construction material. Wageningen: Wageningen University, 2005.

GANAPATHY, P. M. et al. Bamboo panel boards: a state-of-the-art review. Beijing: INBAR, 1999. (Technical report, 12).

GEROTO, P. G. Caracterização anatômica e fisicica - por densitometria de raios $X$ - de colmos de Dendrocalamus asper Backer, Dendrocalamus latiflorus Munro e Guadua angustifolia Kunth. 2014. 112 f. Dissertação (Mestrado em Recursos Florestais) - Escola Superior de Agricultura Luiz de Queiroz, Universidade de São Paulo, Piracicaba, 2014.

GHAVAMI, K. Bambu: um material alternativo na engenharia. Revista Engenharia, Construção Civil, Pesquisa, Engenho, n. 492, p. 23-27, 1992.
GHAVAMI, K.; RODRIGUES, C. S.; PARCIORNIK, S. Bamboo: functionally graded composite material. Asian Journal of Civil Engineering (Building and Housing), v. 4, n. 1, p. 1-10, 2003.

GHAVAMI, K.; MARINHO, A. B. Propriedades físicas e mecânicas do colmo inteiro do bambu da espécie Guadua angustifolia. Agriambi, v. 9, n. 1, p. 107-114, 2005.

GRATANI, L. et al. Growth pattern and photosynthetic activity of different bamboo species growing in the botanical garden of Rome. Flora Morphology, Distribution, Functional Ecology of Plants, v. 203, n. 1, p. 77-84, 2008.

GROSSER, D.; LIESE, W. On the anatomy of Asian bamboos, with special reference to their vascular bundles. Wood Science and Technology, v. 5, n. 4, p. 290-312, 1971.

JAPANESE STANDARDS ASSOCIATION (JSA). JIS A5908: particleboards (foreign standard). Tokyo: JSA, 2015.

KASIM, J. et al. Properties of single-layer urea formaldehyde particleboard manufactured from commonly utilized Malaysian bamboo (Gigantochloa scortechinii). Pertanika Journal of Tropical Agricultural Science, v. 24, n. 2, p. 151-157, 2001.

LI, S. H.; FU, S. Y.; ZHOU, B. L. Reformed bamboo and reformed bamboo/aluminum composite: part I: manufacturing technique, structure and static properties. Journal of Materials Science, v. 29, n. 22, p. 5990-5996, 1994.

LIESE, W. Research on bamboo. Wood Science and Technology, v. 21, n. 3, p. 189-209, 1987.

LIESE, W.; WEINER, G. Ageing of bamboo culms: a review. Wood Science and Technology, v. 30, n. 2, p. 7789, 1996.

NOGATA, F., TAKAHASHI, H. Intelligent functionally graded material: bamboo. Composites Engineering, v. 5, n. 7, p. 743-751, 1995.

PAPADOPOULOS, A. N. et al. Bamboo chips (Bambusa vulgaris) as an alternative lignocellulosic raw material for particleboard manufacture. Holz als Roh- und Werkstoff, v. 62, n. 1, p. 36-39, 2004.

PEREIRA, M. A. R. Projeto bambu: introdução de espécies, manejo, caracterização e aplicações. 2012. 210 f. Tese (Livre Docência) - Faculdade de Engenharia de Bauru, Universidade Estadual Paulista, Bauru, 2012.

PEREIRA, M. A. R.; BERALDO, A. L. Bambu: de corpo e alma. Bauru: Canal, 2007.

QISHENG, Z.; SHENXUE, J.; YONGYU, T. Industrial utilization on bamboo. Beijing: INBAR, 2001. (Technical report, 26). 
ROBERT, J. Mechanical properties of wood-based composite materials. In: FOREST PRODUCTS LABORATORY (Org.). Wood handbook: wood as an engineering material. Madison: FPL, 2010. p. 1-12.

SHARMA, B. et al. Engineered bamboo for structural applications. Construction and Building Materials, v. 81, n. 1, p. 66-73, 2015.

SHARMA, B. et al. Engineered bamboo: state of the art. Proceedings of the Institution of Civil Engineers: Construction Materials, v. 168, n. 2, p. 57-67, 2014.

VALARELLI, I. D. D. et al. Physical and mechanical properties of particleboard bamboo waste bonded with urea formaldehyde and castor oil based adhesive. Revista Matéria, v. 19, n. 1, p. 1-6, 2014.

WIDYORINI, R. et al. Manufacture and properties of citric acid-bonded particleboard made from bamboo materials. European Journal of Wood and Wood Products, v. 74, n. 1, p. 57-65, 2016.

YIPING, L. et al. Bamboo and climate change mitigation: a comparative analysis of carbon sequestration. Beijing: INBAR, 2010. (Technical report, 32).

ZAIA, U. J. et al. Production of particleboards with bamboo (Dendrocalamus giganteus) reinforcement. BioResources, v. 10, n. 1, p. 1424-1433. 2015. 